\title{
ANALISIS KESULITAN GURU MATEMATIKA SMP DALAM PENGEMBANGAN PROFESI DI KABUPATEN WONOSOBO
}

\author{
Endro Wibowo ${ }^{1)}$, Jailani ${ }^{2)}$ \\ SMP Negeri 2 Wonosobo Jawa Tengah ${ }^{1)}$, Universitas Negeri Yogyakarta ${ }^{2)}$ \\ endro7204@gmail.com ${ }^{1)}$, jailani@uny.ac.id ${ }^{2)}$
}

\begin{abstract}
Abstrak
Penelitian ini bertujuan untuk mendeskripsikan persentase banyaknya guru matematika SMP di Kabupaten Wonosobo yang memahami, melaksanakan, dan mengalami kesulitan pada kegiatan pengembangan profesi guru dan upaya yang telah dilakukan untuk mengatasinya. Jenis penelitian ini merupakan penelitian descriptive dengan pendekatan survey. Populasi penelitian ini adalah guru matematika SMP di Kabupaten Wonosobo pada tahun pelajaran 2013/2014 yang sudah diangkat sebagai pegawai negeri sipil. Sampel diambil dengan menggunakan prosedur cluster random sampling. Teknik yang digunakan untuk mengumpulkan data adalah dokumentasi dan quosioner. Teknik analisa data yang dilaksanakan dalam penelitian ini adalah analisis data secara deskriptif. Hasil penelitian menunjukkan bahwa persentase banyaknya guru matematika SMP di Kabupaten Wonosobo yang memahami, melaksanakan, dan mengalami kesulitan pada kegiatan pengembangan profesi guru, masing-masing berada pada kategori sedang, sedikit, dan sangat sedikit. Selanjutnya, upaya yang telah dilakukan oleh guru matematika SMP di Kabupaten Wonosobo untuk mengatasi kesulitan dalam melaksanakan kegiatan pengembangan profesi diantaranya adalah melaksanakan studi lanjut ke jenjang yang lebih banyak.
\end{abstract}

Kata Kunci: kesulitan guru matematika SMP, kegiatan pengembangan profesi guru

\section{ANALYSIS DIFFICULTIES OF JUNIOR HIGH SCHOOL MATHEMATICS TEACHERS ON PROFESSIONAL DEVELOPMENT IN WONOSOBO REGENCY}

\begin{abstract}
The objectives of this research were to describe the percentage of the number of junior high school math teacher in Wonosobo regency that understand, conduct, and face difficulties in teacher professional development activities, and efforts made to overcome the those difficulties. This type of research was a descriptive study with a survey approach. The population was junior high math teachers in Wonosobo regency in the school year 2013/2014 which has become civil servants. Samples were taken by using cluster random sampling procedure. The techniques used to collect the data were documentation and questionnaires. Data analysis techniques implemented in this study was a descriptive analysis. The results showed that the percentage of the number of junior high school math teacher in the Wonosobo regency that understand, conduct, and face difficulties in teacher professional development activities respectively was in category of "average", "few", and "litle of". Efforts that have been made by the junior high math teachers to overcome the difficulties in conducting the professional development activities such as carrying out further studies to a higher level.
\end{abstract}

Keywords: difficulty of junior high school mathematics teachers, teacher professional development activities 


\section{PENDAHULUAN}

Guru sebagai pendidik adalah teladan bagi masyarakat. Teladan masyarakat harus berakhlak mulia dan mampu mempraktekkan apa yang diajarkan dalam kehidupan sehari-hari. Keteladanan guru tersirat dalam Firman Allah Subhanahu Wata'ala dalam Qur'an Surat AshShaff (61) ayat 2 dan 3, yang artinya kurang lebih "Wahai orang-orang yang beriman! Mengapa kamu mengatakan sesuatu yang tidak kamu kerjakan? sangatlah dibenci disisi Allah jika kamu mengatakan apa-apa yang kamu tidak kamu kerjakan" (Hatta, 2009, p.551).

Keteladanan guru hendaknya diartikan dalam arti luas, yaitu: keteladanan dalam berbagai ucapan, sikap, dan perilaku. Contoh nyata keteladanan guru adalah keteladanan Rasulullah Nabi Muhammad Shollallahu 'alaihi wa Sallam yang sangat berhasil sebagai guru manusia: guru bangsa, guru ummat, atau guru paripurna, bahkan dapat dikatakan sebagai guru multidimensi (Hidayatullah, 2009, p.100). Keteladanan Nabi Muhammad Shollallahu 'alaihi wa Sallam telah termaktub dalam Firman Allah Subhanahu Wata'ala dalam Qur'an Surat Al-Ahzab (33) ayat 21 , artinya kurang lebih "Sungguh, telah ada suri teladan yang baik pada (diri) Rasulullah bagimu, (yaitu) bagi orang-orang yang mengharap (rahmat) Allah dan (Kedatangan) hari kiamat dan yang banyak mengingat Allah" (Hatta, 2009, p.420).

Peraturan Menteri Pendidikan dan Kebudayaan Republik Indonesia nomor 65 tahun 2013 tentang Standar Proses Pendidikan Dasar dan Menengah, mengamanatkan: Sesuai dengan Standar Kompetensi Lulusan dan Standar Isi maka prinsip pembelajaran yang digunakan: “... 10. Pembelajaran yang menerapkan nilai-nilai dengan memberi keteladanan (ing ngarso sung tulodo), membangun kemauan (ing madyo mangun karso), dan mengembangkan kreativitas peserta didik dalam proses pembelajaran (tut wuri handayani);...". Prinsip-prinsip tersebut dicetuskan oleh Dewantara yang secara lengkap berbunyi "Ing Ngarso Sun Tulodo, Ing Madyo Mangun Karso, Tutwuri Handayani". Prinsipprinsip tersebut dapat diwujudkan guru Indonesia dalam menjalankan tugas profesionalnya, dengan cara membangun kompetensi pedagogik, kompetensi kepribadian, kompetensi sosial, dan kompetensi profesional sesuai perkembangan ilmu dan teknologi secara berkelanjutan. Makna prinsip pendidikan Ki Hajar Dewantara kurang lebih sebagai berikut; "Ing Ngarso Sung
Tulodo" berarti didepan memberi tauladan, prinsip ini menekankan pada pentingnya modeling atau keteladanan yang merupakan cara yang paling ampuh dalam mengubah perilaku inovasi seseorang. "Ing Madyo Mangun Karso" berarti ditengah menciptakan peluang untuk berprakarsa, prinsip ini memperkuat peran dan fungsi guru sebagai mitra setara (di tengah), serta sebagai fasilitator (menciptakan peluang) para guru mendorong keinginan peserta didik untuk berkarya. "Tutwuri Handayani" berarti dari belakang memberikan dorongan dan arahan, prinsip ini mempunyai makna yang kuat tentang peran dan fungsi guru sebagai motivator dan sebagai pembimbing yang berarti guru tidak membiarkan peserta didik melakukan tindakan yang kurang sesuai dengan tujuan pendidikan. (Yulaelawati, 2009, p.3)

Untuk menjadi guru yang dapat ditauladani, maka harus mendalami dan mengembangkan kompetensinya. Kompetensi mempunyai pengertian dasar membangun dalam "manajemen ilmiah" dan "kebiasaan efisiensi". Terkait dengan guru, pada masa sekarang kompetensi guru diragukan oleh para politikus, media, dan masyarakat di negara-negara yang tingkat ekonomoninya cenderung sedikit dan standar prestasi belajar peserta didik juga relatif sedikit (Days, 2002, p.54). Kompetensi juga erat kaitannya dengan keterampilan praktis, pengetahuan, dan pemahaman dalam suatu pekerjaan yang terencana, dan berhubungan dengan pencapaian tujuan pekerjaan. Atau dengan kata lain kompetensi adalah kemampuan untuk mendemonstrasikan keterampilan dan pengetahuan ke dalam tindakan. (Winterton \& Winterton, 2002, p.25). Selanjutnya Kompetensi di dalam pengajaran dari suatu kurikulum dicapai melalui manajemen perilaku, kecakapan teknis, peraturan budaya dan manipulasi konteks kesadaran diri yang merefleksikan jati diri guru (Brundrett \& Silcock, 2002. p.45). Pendapat lain tentang kompetensi adalah yang dinyatakan oleh Taylor (2007, p.28) bahwa kompetensi sebagai sesuatu yang mendasari karakteristik suatu individu yang berhubungan dengan pencapaian hasil dalam suatu pekerjaan atau situasi. Kompetensi mempunyai definisi yang luas dan meliputi aspek sebagai berikut; motivasi, karakter dan sikap, konsep diri, pengetahuan; perilaku atau keterampilan. Sedangkan Francis (2012, p.3) menyatakan bahwa kompetensi guru pada umumnya mengacu pada seseorang yang mahir dan mampu serta dapat menunjukkan pencapaian tujuan yang lebih banyak. Selanjutnya 
pada Bab IV pasal 8, menyebutkan bahwa guru wajib memiliki kualifikasi akademik, kompetensi, sertifikat pendidik, sehat jasmani dan rohani, serta memiliki kemampuan untuk mewujudkan tujuan pendidikan nasional. Kompetensi guru sebagaimana dimaksud dalam Pasal 8, diuraikan pada pasal 10 ayat 1 bahwa Kompetensi guru meliputi kompetensi pedagogik, kompetensi kepribadian, kompetensi sosial, dan kompetensi profesional yang diperoleh melalui pendidikan profesi. Dari pendapat-pendapat tersebut dapat disimpulkan bahwa kompetensi guru adalah adalah seperangkat sikap, pengetahuan, pemahaman dan keterampilan yang harus dimiliki, dihayati, dan dikuasai oleh seorang guru yang direfleksikan dalam kebiasaan berpikir dan bertindak yang terencana sehingga merupakan manajemen ilmiah dan kebiasaan efisiensi untuk mencapai suatu tujuan pendidikan. Kompetensi guru diklasifikasikan menjadi empat ranah kompetensi yaitu kompetensi pedagogik, kompetensi kepribadian, kompetensi sosial, dan kompetensi profesional.

Guru yang memiliki kompetensi pedagogik, kompetensi kepribadian, kompetensi sosial, dan kompetensi profesional disebut sebagai guru profesional. Guru sebagai tenaga profesional mempunyai fungsi, peran, dan kedudukan yang sangat penting dalam mencapai visi pendidikan 2025 yaitu menciptakan insan Indonesia cerdas dan kompetitif. Besarnya tanggungjawab dan beratnya tugas guru, merupakan salah satu pertimbangan bahwa profesi guru harus dihargai dan dikembangkan sebagai profesi yang bermartabat. Bentuk aktualisasi penghargaan dan pengembangan profesi guru dalam tugas guru sebagai tenaga profesional, maka pemerintah melalui Kementerian Pendidikan Nasional sebagaimana diamanatkan oleh Undang-Undang nomor 20 tahun 2003 tentang Sistem Pendidikan Nasional, Undang Undang nomor 14 tahun 2005 tentang Guru dan Dosen, dan Peraturan Pemerintah nomor 19 tahun 2005 tentang Standar Nasional Pendidikan, akan menfasilitasi guru untuk dapat mengembangkan keprofesiannya secara berkelanjutan. Program pengembangan keprofesian berkelanjutan ini diarahkan untuk dapat memperkecil jarak antara pengetahuan, keterampilan, kompetensi sosial dan kepribadian yang mereka miliki sekarang dengan apa yang menjadi tuntutan ke depan berkaitan dengan profesinya itu. (Dirjen PMPTK, Kemendiknas, 2010, p.1)

Kegiatan pengembangan profesi guru yang berkelanjutan dinyatakan sebagai salah satu unsur utama tugas guru selain kegiatan pembelajaran/pembimbingan dan tugas tambahan lain yang relevan dengan fungsi sekolah/ madrasah yang diberikan angka kredit untuk pengembangan karir guru khususnya dalam kenaikan pangkat/jabatan fungsional guru. Harapannya melalui kegiatan pengembangan keprofesian berkelanjutan akan terwujud guru yang profesional yang bukan hanya sekedar memiliki ilmu pengetahuan yang kuat, tuntas dan tidak setengah-setengah, tetapi tidak kalah pentingnya juga memiliki kepribadian yang matang, kuat dan seimbang. Dengan penguasaan para guru terhadap ilmu pengetahuan dan teknologi yang kuat, tuntas dan tidak setengahsetengah serta kepemilikan kepribadian yang prima, maka diharapkan guru terampil membangkitkan minat peserta didik kepada ilmu pengetahuan dan teknologi melalui penyajian layanan pendidikan yang bermutu. (Direktorat jenderal PMPTK, Kemendiknas. 2010, p.3)

Guru mata pelajaran matematika semestinya mempunyai kompetensi kepribadian dan tingkah laku yang sesuai dengan kegiatan pengembangan profesi karena dijiwai oleh karakteristik mata pelajaran matematika. Permendiknas nomor 22 tahun 2006 tentang Standar Isi, menyebutkan bahwa karakteristik yang merupakan tujuan umum pembelajaran matematika sekolah adalah untuk membekali peserta didik dengan kemampuan berpikir logis, analitis, sistematis, kritis, dan kreatif, serta kemampuan bekerja sama. Kompetensi tersebut diperlukan agar peserta didik dapat memiliki kemampuan memperoleh, mengelola, dan memanfaatkan informasi untuk bertahan hidup pada keadaan yang selalu berubah, tidak pasti, dan kompetitif.

Sebagian besar pengembangan profesi guru matematika sebenarnya bisa diawali dari kegiatan refleksi diri terhadap terlaksananya proses pembelajaran matematika di dalam kelas, dan prestasi belajar matematika peserta didiknya ditinjau dari pencapain tujuan khusus dan tujuan umum mata pelajaran matematika tersebut di atas. Sebagai contoh, dalam memfasilitasi kegiatan pembelajaran peserta didik pada aspekaspek pelajaran matematika, guru seringkali mendapat kesulitan dalam memfasilitasi peserta didik mengkonstruksi pengetahuan pada salah satu aspek atau pada sub aspek mata pelajaran matematika. Hal ini disebabkan oleh beberapa hal yang mungkin terjadi misalnya perbedaan individu peserta didik, kemampuan guru matematika dalam melakukan variasi model pem- 
belajaran, Kemampuan guru dalam memilih/ memodifikasi alat peraga pembelajaran, keterampilan guru dalam menggunakan media pembelajaran, keterbatasan sumber belajar, dan terbatasnya dukungan lingkungan peserta didik.

Untuk mengatasi kesulitan-kesulitan dalam mewujudkan tujuan mata pelajaran matematika maupun dalam membelajarkan peserta didik pada aspek-aspek matematika, sebenarnya guru matematika memiliki banyak cara untuk mengatasi kesulitan tersebut yang apabila pelaksanaannya ditulis dapat digolongkan sebagai karya tulis ilmiah. Diantara cara guru matematika untuk mengatasi kesulitan-kesulitan tersebut adalah pembuatan/modifkasi alat peraga pembelajaran matematika, pembuatan modul/diktat pembelajaran matematika, penerapan model model pembelajaran, berdiskusi dengan teman sejawat baik di unit sekolah maupun pada forum MGMP Matematika, mengikuti dan mengimplementasikan hasil Seminar atau yang sejenisnya tentang pendidikan matematika, mengikuti dan mengimplementasikan hasil pelatihan-pelatihan Continuing Professional Development dan pelatihan-pelaihan lain.

Desimone (2002, p.83) menyatakan bahwa Terdapat enam kegiatan inti yang dapat dihipotesiskan sangat efektif dalam meningkatkan profesionalisme seorang guru dalam menjalankan tugas mengajarnya. Tiga kegiatan inti yang pertama adalah "kegiatan struktural," yang meliputi bentuk atau organisasi kegiatan (kelompok studi, jaringan guru, hubungan mentoring, komite atau gugus tugas, magang, proyek penelitian individu, atau pusat penelitian guru, berbeda dengan workshop, kursus, atau konferensi tradisional), durasi kegiatan (berapa lama peserta menghabiskan waktu di kegiatan, serta rentang waktu yang lebih kegiatan berlangsung), dan sejauh mana partisipasi guru dalam kegiatan (tingkat aktivitasnya). Tiga kegiatan inti kedua adalah sejauh mana aktivitas menawarkan kesempatan untuk belajar aktif (kesempatan bagi guru untuk menjadi aktif terlibat dalam analisis bermakna dalam belajar mengajar, misalnya, dengan meninjau karya peserta didik atau mendapatkan umpan balik pada pengajaran mereka), sejauh mana aktivitas mempromosikan koherensi dalam guru pengembangan professional (dengan memasukkan pengalaman yang konsisten dengan guru tujuan, sesuai dengan standar negara dan penilaian, dan mendorong terus komunikasi profesional antara guru), dan sejauh mana aktivitas tersebut memiliki konten focus (sejauh mana aktivitas tersebut difokuskan pada peningkatan dan memperdalam pengetahuan konten guru dalam matematika dan ilmu pengetahuan).

Garet (2001, p.1) menyatakan bahwa terdapat tiga kegiatan pengembangan profesional guru yang secara signifikan memberikan efek positif pada peningkatan guru dalam pengetahuan dan keterampilan serta perubahan dalam praktek pembelajaran di kelas: (a) fokus pada isi pengetahuan, (b) kesempatan untuk belajar aktif; dan (c) koherensi dengan kegiatan belajar lainnya. Hal ini dilaksanakan terutama melalui struktur inti yang secara signifikan mempengaruhi pembelajaran guru, yaitu: (a) bentuk kegiatan (misalnya, lokakarya vs kelompok studi), (b) partisipasi kolektif guru dari sekolah yang sama, kelas, atau subjek, dan (c) durasi kegiatan. Suparlan (2008, p.182) menyatakan bahwa pembinaan profesionalisme guru dapat dilakukan melalui kegiatan berikut; peningkatan kualifikasi melalui jenjang pendidikan formal, peningkatan kompetensi melalui pendidikan dan latihan, peningkatan kompetensi melalui kegiatan yang dirancang oleh organisasi profesi, dan belajar mandiri. Leikin \& Zazkis (2010, p.221) menyatakan bahwa penelitian mutakhir guru matematika dalam mengatasi masalah yang dihadapi dalam kegiatan pembelajaran maupun dalam pengembangan profesi, diringkas ke dalam tiga kategori utama, yaitu: isi, metoda, dan efektivitas. Demonte (2013, p.6) menyatakan bahwa menurut penelitian kegiatan pengembangan profesi guru berisi lima karakteristik berikut: (1) sejalan dengan tujuan sekolah, standar kabupaten, standar pemerintah, penilaian, dan kegiatan belajar profesional lainnya (2) Fokus pada kompetensi inti dan pemodelan strategi pengajaran untuk kompetensi inti yang dimaksud. (3)Termasuk kesempatan untuk belajar aktif dalam strategi pengajaran baru. (4) memberikan kesempatan bagi guru untuk berkolaborasi (5)Termasuk tindak lanjut dan umpan balik yang berkesinambungan.

Kegiatan pengembangan profesi guru matematika yang disesuaikan dengan Peraturan Menteri Negara Pemberdayaan Aparatur Negara dan Reformasi Birokrasi nomor 16 tahun 2009 tentang Jabatan Fungsional Guru dan Angka Kreditnya, dibedakan dalam tiga kelompok kegiatan yaitu kegiatan pengembangan diri, kegiatan publikasi ilmiah, dan kegiatan karya inovasi. Kegiatan pengembangan diri pada kegiatan pengembangan profesi guru matematika adalah kegiatan yang dilakukan guru matematika untuk meningkatkan kompetensi dan 
keprofesiannya. Kegiatan tersebut dilakukan melalui pendidikan dan pelatihan (diklat) fungsional dan/atau melalui kegiatan kolektif guru. Secara rinci penjelasan kedua macam kegiatan dimaksud sebagai berikut; (1) mengikuti diklat fungsional terkait dengan tugas guru secara umum, misalnya: workshop, diklat, penataran, dan kegiatan lain yang sejenis tentang kurikulum, maupun terkait dengan tugas guru matematika secara khusus, misalnya: workshop, diklat, penataran, dan kegiatan lain yang sejenis tentang pembelajaran dan pengembangan teori matematika, (2) mengikuti kegiatan kolektif guru matematika, misalnya: kegiatan MGMP, seminar, lokakarya, inhouse training, koloqium, diskusi panel, dan kegiatan lain yang sejenis).

Publikasi ilmiah adalah karya tulis ilmiah yang telah dipublikasikan kepada masyarakat sebagai bentuk kontribusi guru terhadap peningkatan kualitas proses pembelajaran di sekolah dan pengembangan dunia pendidikan secara umum. Publikasi ilmiah mencakup 3 kelompok kegiatan, yaitu: (1) Presentasi sebagai pemakalah pada forum ilmiah matematika dan atau pendidikan matematika, (2) Publikasi hasil penelitian atau gagasan inovatif pada bidang pendidikan Matematika, meliputi; Membuat Laporan hasil penelitian, atau Tinjauan ilmiah, Tulisan Ilmiah popular, Artikel Ilmiah, (3) Publikasi buku teks pelajaran, buku pengayaan dan/atau pedoman guru, meliputi: membuat buku pelajaran matematika, membuat buku matematika, membuat modul pembelajaran matematika, membuat diktat pembelajaran matematika, membuat terjemahan buku matematika, membuat buku pedoman guru matematika.

Karya Inovatif Pendidikan Matematika adalah karya yang bersifat pengembangan, modifikasi atau penemuan baru sebagai bentuk kontribusi guru terhadap peningkatan kualitas proses pembelajaran di sekolah dan pengembangan dunia pendidikan, sains/teknologi, dan seni. Karya inovatif ini mencakup: (1) Menemukan teknologi tepatguna; (membuat media pembelajaran/bahan ajar Matematika interaktif berbasis komputer, membuat program aplikasi komputer, membuat alat/mesin yang bermanfaat untuk pendidikan matematika atau masyarakat, melakukan eksperimen/percobaan sains/teknologi dan membuat laporan, melakukan pengembangan metodologi/evaluasi pembelajaran dan membuat laporan kegiatannya. (1) menemukan/ menciptakan karya seni matematika, (2) membuat/memodifikasi alat peraga/alat pelajaran/alat praktikum matematika, (3) mengikuti pengem- bangan penyusunan standar pedoman pembelajaran matematika. (Permendiknas dan Reformasi Birokrasi No.16 tahun 2009, p.17).

Kesimpulan dari beberapa pendapat diatas adalah kegiatan pengembangan profesi guru matematika merupakan salah satu upaya untuk mengatasi beberapa masalah yang muncul dalam proses pembelajaran matematka peserta didik yang difasiltasi guru terkait dengan isi pelajaran, metode pembelajaran, maupun hasil pembelajaran, dimana karekteristik kegiatan pengembangan profesi guru harus sejalan dengan tujuan sekolah, standar kabupaten, standar pemerintah, standar penilaian, yang dapat dilaksanakan melalui peningkatan kualifikasi melalui jenjang pendidikan formal, pendidikan dan latihan, kegiatan yang dirancang oleh organisasi profesi, dan belajar mandiri, serta dibagi menjadi tiga subbagian, yaitu; kegiatan pengembangan diri, Publikasi Ilmiah, dan Karya Inofatif.

Penghargaan dan pengembangan profesi guru sejak diaturnya PAK (Penilaian Angka Kredit) bagi guru dengan Peraturan Pemerintah nomor 3 tahun 1980, Kepmenpan nomor 26 tahun 1989, Kepmenpan nomor 84 tahun 1993 yang dijabarkan dengan SKB Mendikbud dan BKN nomor 433/P/1993 dan nomor 25 tahun 1993, Juknis Mendikbud nomor 025/0/1995, sampai dengan lahirnya UU Guru dan Dosen dengan tujuan agar guru berlomba-lomba untuk berprestasi. Peraturan terbaru mengenai PAK (Penilaian Angka Kredit) guru menurut Pasal 17 Peraturan Menteri Negara Pemberdayaan Aparatur Negara dan Reformasi Birokrasi nomor 16 tahun 2009 tentang Jabatan Fungsional Guru dan Angka Kreditnya menuntut guru untuk melakukan kegiatan pengembangan profesi mulai dari jabatan guru pertama golongan IIIA. Guru yang tidak melakukan kegiatan pengembangan profesi tidak bisa naik pangkat, jabatan, dan golongan ruang. Akibatnya, kalau dengan peraturan lama guru bisa naik pangkat/golongan setiap dua tahun dan akhirnya berhenti pada golongan ruang IVA, maka dengan aturan baru guru yang tidak mau melakukan kegiatan pengembangan profesi bisa berhenti kenaikan pangkat dan golongannya pada golongan IIIA.

Data Dinas Pendidikan Kabupaten Wonosobo yang diperoleh pada Bulan April 2013 menunjukkan belum ada guru matematika SMP di Kabupaten Wonosobo yang mencapai golongan ruang IV-B. Berdasarkan hasil wawancara secara acak dengan beberapa orang guru matematika SMP di Kabupaten Wonosobo yang sudah diangkat sebagai pegawai negeri sipil 
bergolongan ruang IV-A dengan masa kerja golongan 10 tahun, diperoleh informasi bahwa selama 10 tahun tidak mengajukan usulan kenaikan pangkat menuju golongan ruang IV-B karena belum melaksanakan kegiatan pengembangan profesi. Dari beberapa orang guru yang diwanwancarai pada Penilaian Angka Kredit (PAK) unsur utama pengembangan profesi ratarata nilainya masih kosong. Hasil wawancara dengan beberapa orang guru matematika SMP di Kabupaten Wonosobo yang sudah diangkat sebagai pegawai negeri sipil bergolongan ruang di bawah IV-A, hampir semua guru yang diwawancarai secara acak belum memiliki nilai pada PAK unsur utama pengembangan profesi.

Peneliti menduga bahwa apabila kondisi tersebut dibiarkan begitu saja, maka akan merugikan peserta didik, guru yang bersangkutan, pihak sekolah, masyarakat, dan negara secara umum. Peserta didik akan rugi dengan sebab guru yang mendidiknya tidak memiliki profesionalitas yang berkembang secara maksimal. Apabila peserta didik dirugikan implikasinya orang tua, masyarakat dan negara juga dirugikan. Guru yang bersangkutan juga akan rugi karena tidak mendapat penghargaan yang maksimal yaitu tidak bisa mengikuti kenaikan pangkat/jabatan fungsional guru secara maksimal, bahkan dihilangkan haknya untuk mendapat tunjangan profesi, tunjangan fungsional dan maslahat tambahan.

Berbagai hal yang mungkin menjadi penyebab masih kosongnya nilai unsur utama pengembangan profesi pada PAK (Penilaian Angka Kredit) bagi guru matematika SMP di Kabupaten Wonosobo, diantaranya adalah: pertama; guru belum memahami kebijakan pemerintah terhadap jabatan fungsional dan penilaian angka kredit bagi guru. Kedua; guru belum memahami makna kegiatan pengembangan profesi terhadap kemajuan prestasi belajar matematika peserta didik. Ketiga; guru mengalami kesulitan dalam melaksanakan kegiatan pengembangan profesi tertentu. Keempat; guru belum merasa perlu melaksanakan kegiatan pengembangan profesi. Peneliti berpendapat bahwa penyebab ketiga inilah yang menjadi alasan utama masih kosongnya nilai unsur utama pengembangan profesi pada PAK (Penilaian Angka Kredit) guru matematika SMP, maka rumusan masalah pada penelitian ini dapat disusun sebagai berikut: bagaimana persentase jumlah guru matematika SMP di Kabupaten Wonosobo yang telah memahami kegiatan pengembangan profesi?, bagaimana persentase jumlah guru matematika SMP di Kabupaten Wonosobo yang telah melaksanakan kegiatan pengembangan profesi?, Bagaimana persentase jumlah guru matematika SMP di Kabupaten Wonosobo yang mengalami kesulitan dalam melaksanakan kegiatan pengembangan profesi?, dan Upaya apa sajakah yang telah dilakukan oleh guru matematika SMP di Kabupaten Wonosobo untuk mengatasi kesulitan yang dialaminya?

Berdasarkan rumusan masalah tersebut maka penelitian ini bertujuan untuk mendeskripsikan: Persentase jumlah guru matematika SMP di Kabupaten Wonosobo yang telah memahami kegiatan pengembangan profesi, Persentase jumlah guru matematika SMP di Kabupaten Wonosobo yang telah melaksanakan kegiatan pengembangan profesi, Persentase jumlah guru matematika SMP di Kabupaten Wonosobo yang mengalami kesulitan dalam melaksanakan kegiatan pengembangan profesi, dan Upaya yang telah dilakukan oleh guru matematika SMP di Kabupaten Wonosobo untuk mengatasi kesulitan yang dialami dalam melaksanakan kegiatan pengembangan profesi

\section{METODE}

Penelitian ini digolongkan dalam penelitian descriptive dengan pendekatan survey. Penelitian dilaksanakan di SMP se-Kabupaten Wonosobo, Provinsi Jawa Tengah. Pengambilan data dilaksanakan dimulai sejak 1 November 2013 sampai dengan 30 Januari 2014 melalui pertemuan langsung dengan responden di Sekolah atau di rumah, pertemuan MGMP Matematika SMP Kabupaten Wonosobo, pertemuan dengan kepala sekolah, dan pertemuan dengan kepegawaian dinas dikpora Kabupaten Wonosobo.

Populasi dalam penelitian ini adalah guru matematika SMP di Kabupaten Wonosobo pada tahun pelajaran 2013/2014 yang sudah diangkat sebagai pegawai negeri sipil yang seluruhnya berjumlah 131 orang. Pengambilan sampel menggunakan prosedur clustering random sampling. Sampel diambil dari seluruh guru matematika SMP yang sudah berstatus sebagai pegawai negeri sipil di satu SMP yang terletak di wilayah kota kecamatan dan di satu SMP yang terletak di wilayah pedesaan kecamatan, dimana penentuan SMP yang akan diambil sampelnya ditetapkan secara acak. Hasil Cluster random sampling diperoleh 15 SMP di wilayah kota kecamatan dan 15 SMP diwilayah pedesaan 
ditambah 2 SMP Swasta. Sampel seluruhnya berjumlah 86 orang.

Teknik yang digunakan untuk mengumpulkan data menggunakan dua cara yaitu dengan: dokumentasi dan quosioner. Instrumen yang digunakan untuk penelitian adalah (1) dokumen data guru SMP se-Kabupaten Wonosobo yang diperoleh dari Dinas Pendidikan Pemuda dan Olah Raga Kabupaten Wonosobo digunakan untuk melihat Identitas dan pemetaan guru matematika SMP di Kabupaten Wonosobo, (2) Angket yang berisi pertanyaan dan atau pernyataan terkait dengan kegiatan pengembangan profesi guru matematika SMP di Kabupaten Wonosobo. Penelitian ini menggunakan empat angket, yaitu angket A berisi pertanyaan dan atau pernyataan tentang pemahaman guru matematika SMP di Kabupaten Wonosobo terhadap kegiatan pengembangan profesi, Angket B berisi pertanyaan dan atau pernyataan tentang pelaksanaan kegiatan pengembangan profesi oleh guru matematika SMP di Kabupaten Wonosobo, Angket $\mathrm{C}$ berisi tentang kesulitan guru matematika SMP di Kabupaten Wonosobo dalam melaksanakan kegiatan pengembangan profesi, dan angket $\mathrm{D}$ berisi tentang upaya yang telah dilaksanakan guru matematika SMP di Kabupaten Wonosobo dalam mengatasi kesulitan pada pelaksanaan kegiatan pengembangan profesi.

Bukti validitas Instrumen dalam penelitian ini terdiri atas validitas isi (content validity) dan validitas konstruk (construct validity). Bukti validitas isi (content validity) yaitu untuk mengetahui sejauh mana instrumen yang digunakan dalam penelitian telah mencerminkan keseluruhan aspek yang akan diukur. Langkahlangkah yang dilakukan dalam menentukan bukti validitas isi adalah; (1) peneliti menyusun menyusun butir-butir instrumen berdasarkan indikator yang ditetapkan pada kisi-kisi, (2) butir-butir instrumen yang telah disusun dikonsultasikan dengan ahli untuk memeriksa isi instrumen secara sistematis serta mengevaluasi relevansi instrumen dengan variabel yang ditentukan sehingga diperoleh expert judgment. Ahli yang terlibat dalam validasi (sebagai validator) instrumen dalam penelitian ini adalah ibu Dr. Heri Retnawati dan bapak Dr. Ali Mahmudi.

Validitas konstruk (construct validity), yaitu untuk mengukur sejauhmana item instrumen mengukur trait atau konstrak teoretik yang diukurnya. Instrumen untuk memperoleh data pemahaman guru matematika SMP terhadap kegiatan pengembangan profesi terdiri dari 10 butir pernyataan. Setelah instrumen diujicobakan dan dilakukan analisis dengan bantuan program SPSS diperoleh nilai Kaiser-MayerOlkin (KMO) sebesar 0,821 yang menandakan bahwa secara konstruk instumen valid karena sudah memenuhi batas 0,50. Dengan melihat total variance explained yang nilai eigenvaluenya lebih dari 1, maka dari 10 item pernyataan yang ada pada angket pemahaman guru terhadap kegiatan pengembangan profesi tersebut konstruknya mengelompok menjadi 2 faktor. Selanjutnya dengan melihat rotated component matrix ${ }^{a}$ pengelompokan faktorfaktornya adalah sebagai berikut: Faktor pertama item no 5, 6, 7, 8, 9. Faktor kedua item no 1 , 2, 3, 4, 10 .

Estimasi reliabilitas instrumen pada penelitian ini menggunakan Cronbach's alpha coefficient. Untuk mengestimasi Cronbach's alpha coefficient (koefisien reliabilitas) instrumen digunakan formula Alpha Cronbach (Ebel \& Frisbie, 1986, p.79). Berdasarkan hasil perhitungan secara manual menggunakan program excel maupun dengan bantuan program SPSS 20 for windows diperoleh koefisien reliabilitas tes pemahaman guru matematika SMP di Kabupaten Wonosobo terhadap kegiatan pengembangan profesi guru sebesar 0,873 . Sedangkan hasil perhitungan dengan program excel diperoleh SEM sebesar 1,178. Hal ini menunjukkan bahwa reliabilitas instrumen pemahaman guru matematika SMP di Kabupaten Wonosobo terhadap kegiatan pengembangan profesi guru termasuk dalam kategori baik.

Teknik analisis data yang dilakukan dalam penelitian ini adalah analisis data secara deskriptif. Teknik analisis ini digunakan untuk mendeskripsikan data penelitian apa adanya dan tidak digunakan untuk mengambil kesimpulan statistik (Mulyatiningsih, 2012, p.38). Analisis deskriptif data dalam penelitian ini terdiri dari empat, yaitu;

Deskriptif terhadap data jumlah guru matematika SMP di Kabupaten Wonosobo yang telah memahami kegiatan pengembangan profesi, menggunakan kriteria pada tabel 1 . 
Tabel 1. Penentuan Kriteria Persentase Banyaknya Guru yang Memahami Kegiatan Pengembangan Profesi

\begin{tabular}{cc}
\hline Interval & Kriteria \\
\hline $0 \%$ & Tidak ada yang memahami \\
$0 \%<X \leq 25 \%$ & sangat sangat sedikit \\
$25 \%<X \leq 50 \%$ & sedikit \\
$50 \%<X \leq 70 \%$ & sedang \\
$70 \%<X \leq 85 \%$ & banyak \\
$85 \%<X \leq 100 \%$ & sangat banyak \\
\hline
\end{tabular}

Keterangan: $X=$ persentase jumlah guru yang memahami kegiatan penegmbangan profesi

Deskripsi data banyaknya guru matematika SMP di Kabupaten Wonosobo yang telah melaksanakan kegiatan pengembangan profesi, menggunakan kriteria pada tabel 2 .

Tabel 2. Penentuan Kriteria Persentase Banyaknya Guru yang Melaksanakan Kegiatan Pengembangan Profesi

\begin{tabular}{cc}
\hline Interval & Kriteria \\
\hline $0 \%$ & Tidak ada yang melaksanakan \\
$0 \%<\mathrm{X} \leq 25 \%$ & sangat sangat sedikit \\
$25 \%<\mathrm{X} \leq 50 \%$ & sedikit \\
$50 \%<\mathrm{X} \leq 70 \%$ & sedang \\
$70 \%<\mathrm{X} \leq 85 \%$ & bangat banyak \\
$85 \%<\mathrm{X} \leq 100 \%$ & $\mathrm{X}=$ persentase jumlah guru yang \\
- Keterangan: $\mathrm{X}$ &
\end{tabular}

Deskripsi data banyaknya guru matematika SMP di Kabupaten Wonosobo yang mengalami kesulitan dalam melaksanakan kegiatan pengembangan profesi guru, menggunakan kriteria pada tabel 3 .

Tabel 3. Penentuan Kriteria Persentase

Banyaknya Guru yang Kesulitan dalam Kegiatan Pengembangan Profesi

\begin{tabular}{cc}
\hline Interval & Kriteria \\
\hline $0 \%$ & Tidak ada yang Kesulitan \\
$0 \%<\mathrm{X} \leq 25 \%$ & sangat sangat sedikit \\
$25 \%<\mathrm{X} \leq 50 \%$ & sedikit \\
$50 \%<\mathrm{X} \leq 70 \%$ & sedang \\
$70 \%<\mathrm{X} \leq 85 \%$ & banyak \\
$85 \%<\mathrm{X} \leq 100 \%$ & sangat banyak \\
\hline
\end{tabular}

Keterangan: $\mathrm{X}=$ persentase jumlah guru yang kesulitan dalam kegiatan pengembangan profesi

Deskripsi data upaya yang pernah dilakukan guru matematika SMP di Kabupaten Wonosobo untuk mengatasi Kesulitan dalam Melaksanakan Kegiatan Pengembangan Profesi, dideskripsikan dengan menggunakan kriteria pada tabel 4 .
Tabel 4. Penentuan Kriteria Persentase Banyaknya Guru yang Berpupaya Mengatasi Kesulitan dalam Kegiatan Pengembangan Profesi

\begin{tabular}{cc}
\hline Interval & Kriteria \\
\hline $0 \%$ & Tidak ada melakukan upaya \\
$0 \%<\mathrm{X} \leq 25 \%$ & sangat sangat sedikit \\
$25 \%<\mathrm{X} \leq 50 \%$ & sedikit \\
$50 \%<\mathrm{X} \leq 70 \%$ & sedang \\
$70 \%<\mathrm{X} \leq 85 \%$ & banyak \\
$85 \%<\mathrm{X} \leq 100 \%$ & sangat banyak
\end{tabular}

Keterangan: $\mathrm{X}=$ persentase jumlah guru banyaknya guru yang berupaya mengatasi kesulitan dalam kegiatan pengembangan profesi

\section{HASIL DAN PEMBAHASAN}

\section{Hasil Penelitian}

Persentase Jumlah Guru Matematika SMP di Kabupaten Wonosobo yang telah Memahami Kegiatan Pengembangan Profesi secara umum termasuk dalam kategori sedang. Persentase jumlah guru matematika SMP di Kabupaten Wonosobo yang telah memahami kegiatan pengembangan profesi persubbagian, dapat dideskripsikan sebagai berikut; yang telah memahami subbagian pengembangan diri masuk dalam kategori banyak, yang telah memahami subbagian publikasi ilmiah masuk dalam kategori sedang, yang telah memahami subbagian karya inovatif masuk dalam kategori sedang. Secara rinci disajikan pada tabel 5.

Tabel 5. Persentase Jumlah Guru yang telah Memahami Kegiatan Pengembangan Profesi Persubbagian

\begin{tabular}{ccc}
\hline Subbagian & Persentase & Kategori \\
\hline pengembangan diri & $74,12 \%$ & Banyak \\
publikasi ilmiah & $51,18 \%$ & Sedang \\
karya inovatif & $52,94 \%$ & Sedang \\
\hline
\end{tabular}

Persentase jumlah guru matematika SMP di Kabupaten Wonosobo yang telah memahami kegiatan pengembangan profesi persubbagian, dalam bentuk diagram dapat disajikan pada gambar 1. 


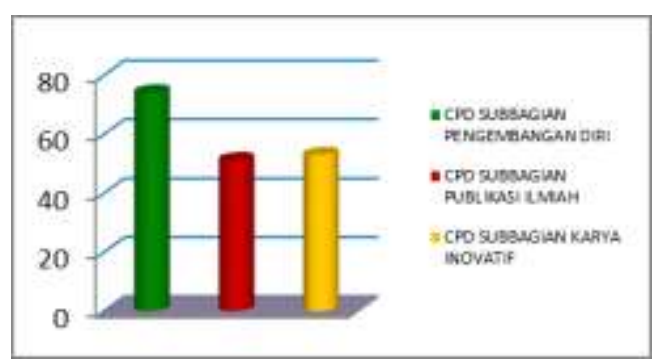

Gambar 1. Diagram Persentase Jumlah Guru Matematika SMP di Kabupaten Wonosobo yang telah Memahami Kegiatan Pengembangan Profesi Persubbagian

Persentase Jumlah Guru Matematika SMP di Kabupaten Wonosobo yang telah melaksanakan Kegiatan Pengembangan Profesi, Secara umum pada kategori sedikit. Keterlaksanaan kegiatan pengembangan profesi guru matematika SMP di Kabupaten Wonosobo persubbagian; pada subbagian pengembangan diri termasuk dalam kategori sedang, pada subbagian publikasi ilmiah termasuk dalam kategori sangat sedikit, dan pada subbagian karya inovatif termasuk dalam kategori sangat sedikit. Keterlaksanaan pengembangan profesi persubbagian secara rinci disajikan pada tabel 6 .

Tabel 6. Persentase Jumlah Guru yang telah Melaksanakan Kegiatan Pengembangan Profesi Persubbagian

\begin{tabular}{ccc}
\hline Subbagian & Persentase & Kategori \\
\hline pengembangan diri & $50,73 \%$ & Sedang \\
publikasi ilmiah & $9,73 \%$ & sangat sedikit \\
karya inovatif & $19,57 \%$ & sangat sedikit \\
\hline
\end{tabular}

Perbedaan persentase jumlah guru matematika SMP di Kabupaten Wonosobo yang telah melaksanakan kegiatan pengembangan profesi antara subbagian Pengembangan Diri, subbagian Pelaksanaan Publikasi Ilmiah, subbagian pelaksanaan Karya Inovatif apabila dibuat diagram, dapat disajikan pada gambar 2.

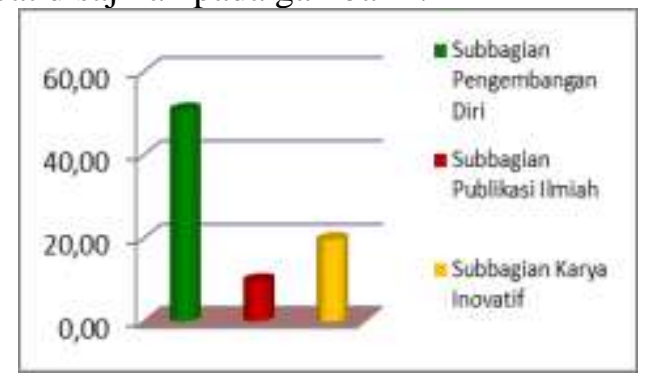

Gambar 2. Diagram Persentase Jumlah Guru Matematika SMP di Kabupaten Wonosobo yang telah Melaksanakan Kegiatan Pengembangan Profesi Persubbagian
Persentase Jumlah Guru Matematika SMP di Kabupaten Wonosobo yang mengalami kesulitan dalam melaksanakan kegiatan pengembangan profesi, secara umum pada kategori sangat sedikit. persentase jumlah guru matematika smp di kabupaten wonosobo yang mengalami kesulitan dalam melaksanakan kegiatan pengembangan profesi pada subbagian pengembangan diri dalam kategori sangat sedikit, pada subbagian publikasi ilmiah dalam kategori sangat sedikit, dan pada subbagian karya inovatif pada kategori sangat sedikit. Secara rinci Persentase Jumlah guru Matematika SMP yang Mengalami Kesulitan dalam Pelaksanaan Kegiatan Pengembangan Profesi persubbagian disajikan pada tabel 7.

Tabel 7. Persentase Jumlah Guru Matematika

SMP yang Mengalami Kesulitan dalam

Pelaksanaan Kegiatan Pengembangan Profesi Persubbagian

\begin{tabular}{ccc}
\hline Subbagian & Persentase & Kategori \\
\hline pengembangan diri & $17,63 \%$ & Sangat sedikit \\
publikasi ilmiah & $23,32 \%$ & sangat sedikit \\
karya inovatif & $21,06 \%$ & Sangat sedikit \\
\hline
\end{tabular}

Perbandingan Persentase Jumlah guru Matematika SMP yang Mengalami Kesulitan dalam Pelaksanaan Kegiatan Pengembangan Profesi persubbagian dapat disajikan pada gambar 3.

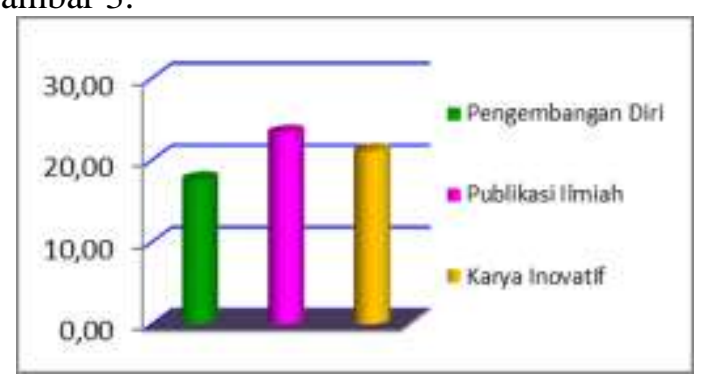

Gambar 3. Diagram Persentase Jumlah guru Matematika SMP yang Mengalami Kesulitan dalam Pelaksanaan Kegiatan Pengembangan Profesi

Deskripsi upaya yang telah dilakukan oleh guru matematika SMP di Kabupaten Wonosobo untuk mengatasi kesulitan dalam melaksanakan kegiatan pengembangan profesi adalah sebagai berikut; mempelajari Peraturan Menteri Negara Pemberdayaan Aparatur Negara dan Reformasi Birokrasi Nomor 16 Tahun 2009 tentang Jabatan Fungsional Guru dan Angka Kreditnya, dalam kategori sedang, melaksanakan tugas dari kepala sekolah atau dinas 
pendidikan, bila ditugasi untuk mengikuti kegiatan diklat fungsional guru matematika (sosialisasi/bintek/workshop/dll) ataupun kegiatan kolektif guru matematika (MGMP/Seminar/ Lokakarya/dll), dalam kategori sangat banyak, mencari informasi melalui internet atau sumber informasi lain tentang diselenggarakannya kegiatan diklat fungsional guru matematika maupun kegiatan kolektif guru matematika, kemudian mengikutinya dengan biaya sendiri), dalam kategori sangat sedikit, melaksanakan studi lanjut ke jenjang yang lebih tinggi (S1/S2/) untuk meningkatkan kompetensi diri sebagai guru matematika), dalam kategori sedikit, mencoba melaksanakan penelitian tindakan kelas pembelajaran matematika walaupun belum membuat laporannya), dalam kategori sedang, mencoba melaksanakan penelitian tindakan kelas pembelajaran matematika dan membuat laporannya), dalam kategori sedikit, mencoba mempresentasikan hasil laporan penelitian tindakan kelas pembelajaran matematika di forum rapat guru di sekolah), dalam kategori sangat sedikit, mencoba mempresentasikan hasil laporan penelitian tindakan kelas di forum MGMP Matematika), dalam kategori sangat sedikit, mencoba membuat artikel pendidikan matematika (hasil penelitian tindakan kelas/ tinjauan pustaka) *) untuk dimuat di Jurnal), dalam kategori sangat sedikit, mencoba membuat artikel pendidikan matematika (hasil penelitian tindakan kelas/ tinjauan pustaka) *) untuk dimuat di media masa (surat kabar/majalah/ tabloit/dll)*)), dalam kategori sangat sedikit, mencoba membuat modul/diktat pembelajaran matematika), dalam kategori sedikit, mencoba membuat buku matematika (buku siswa/buku pengayaan/buku terjemahan/buku pedoman guru)*)), dalam kategori sangat sedikit, mencoba membuat program aplikasi komputer untuk pembelajaran matematika inter aktif walaupun belum membuat laporan), dalam kategori sangat sedikit, mencoba membuat program aplikasi komputer untuk pembelajaran matematika inter aktif dan membuat laporannya), dalam kategori sangat sedikit,

\section{Pembahasan}

Persentase Jumlah Guru Matematika SMP di Kabupaten Wonosobo yang telah Memahami Kegiatan Pengembangan Profesi. Persentase jumlah guru matematika SMP di Kabupaten Wonosobo yang telah memahami kegiatan pengembangan profesi secara umum dalam kategori sedang, rinciannya; pada subbagian pengembangan diri dalam kategori banyak, pada subbagian publikasi ilmiah dalam kategori sedang, dan pada subbagian karya inovatif dalam kategori sedang. Hal tersebut menunjukkan bahwa sebagian besar guru matematika SMP di Kabupaten Wonosobo sudah memahami dengan baik kegiatan pengembangan profesi subbagian pengembangan diri, namun untuk kegiatan pengembangan profesi subbagian publikasi ilmiah dan karya inovatif masih perlu ditingkatkan pemahamannya. Kegiatan pengembangan diri lebih mudah dipahami karena hanya menuntut pelaksananya menjadi peserta kegiatan, tidak menuntut pelaksananya sebagai narasumber/pemrasaran yang memerlukan kreatifitas maupun inovasi. Kegiatan pengembangan diri merupakan upaya-upaya untuk meningkatkan profesionalisme diri agar memiliki kompetensi yang sesuai dengan peraturan perundang-undangan agar mampu melaksanakan tugas pokok dan kewajibannya dalam pembelajaran/pembimbingan termasuk pelaksanaan tugas-tugas tambahan yang relevan dengan fungsi sekolah/ madrasah (Kemendiknas Dirjen PMPTK, 2010, p.13)

Persentase jumlah Guru Matematika SMP di Kabupaten Wonosobo yang telah Melaksanakan Kegiatan Pengembangan Profesi secara umum pada kategori sedikit. Rinciannya; pada subbagian pengembangan diri dalam kategori sedang, pada subbagian publikasi ilmiah dalam kategori sangat sedikit, dan pada subbagian karya inovatif pada kategori sangat sedikit. Hal tersebut menunjukkan bahwa keterlaksanaan kegiatan pengembangan profesi pada subbagian "pengembangan diri" lebih banyak dibanding keterlaksaaan kegiatan pengembangan profesi pada subbagian "publikasi ilmiah" dan subbagian "karya inovatif". Persentase banyaknya guru yang telah melaksanakan kegiatan pengembangan profesi, berbanding lurus dengan persentase banyaknya guru Matematika SMP yang telah memahami kegiatan pengembangan profesi. Perbandingan tersebut disajikan dalam tabel 8.

Tabel 8. Perbandingan Persentase Banyaknya Guru yang Memahami dan yang Melaksanakan Kegiatan Pengembangan Profesi

\begin{tabular}{lcc}
\hline & $\begin{array}{c}\text { Guru yang } \\
\text { Memahami }\end{array}$ & $\begin{array}{c}\text { Guru yang } \\
\text { Melaksanakan }\end{array}$ \\
\hline Pengembangan Diri & $74,12 \%$ & $50,73 \%$ \\
Publikasi Ilmiah & $51,18 \%$ & $9,73 \%$ \\
Karya Inofasi & $52,94 \%$ & $19,57 \%$ \\
\hline
\end{tabular}


Tabel tersebut menunjukkan adanya kesesuaian antara pemahaman dan pelaksanaan kegiatan pengembangan profesi, bahwa yang dilaksanakan oleh seorang guru adalah sesuatu yang telah dipahami tetapi tidak semua yang telah dipahami bisa dilaksanakan. Pada tabel tersebut terlihat bahwa sebagian besar guru matematika SMP di Kabupaten Wonosobo telah memahami kegiatan pengembangan diri, tetapi belum semua guru yang telah paham dapat melaksanakannya. Kegiatan pengembangan profesi guru yang mencakup tiga subbagian yaitu Subbagian kegiatan pengembangan diri, subbagian publikasi Ilmiah, dan subbagian karya inofatif seharusnya dilaksanakan oleh guru secara berkelanjutan, agar guru dapat selalu menjaga dan meningkatkan profesionalismenya, tidak sekadar untuk pemenuhan angka kredit.

Hal tersebut di atas sesuai dengan yang dinyatakan oleh Mahsunah, dkk. (2012, p.27) bahwa meskipun angka kredit seorang guru diasumsikan telah memenuhi persyaratan untuk kenaikan pangkat dan jabatan fungsional tertentu, guru tetap wajib melakukan kegiatan Pengembangan Keprofesian Berkelanjutan. Kegiatan pengembangan keprofesian berkelanjutan atau sering disebut juga dengan CPD (Continuing Professional Development) sebenarnya merupakan sebuah kebutuhan bagi semua guru, karena tidak mungkin selalu mengadakan pelatihan guru baru untuk menyediakan guru masa depan dengan semua guru harus mengetahui tentang subjek yang akan diajarkan dan memahami bagaimana mengajar agar peserta didik belajar dan bagaimana mengajar agar peserta didik berpartisipasi secara efektif. Sebagaimana yang dinyatakan oleh Smith (2002, p.1) bahwa kebutuhan CPD bagi guru adalah untuk semua guru mata pelajaran. Namun, dengan melihat karakteristik matematika dan ilmu pengetahuan lainnya maka harus ada persyaratan khusus pada pelaksanaan CPD bagi guru matematika yang baru maupun guru matematika yang sudah berpengalaman, bagi guru matematika yang memiliki latar belakang pendidikan matematika maupun guru matematika yang tidak memiliki latar belakang matematika.

Sedikitnya persentase jumlah guru matematika SMP di Kabupaten Wonosobo, hendaknya menjadi bahan renungan bagi guru matematika SMP di Kabupaten Wonosobo khususnya dan semua guru pada umumnya sampai sejauh mana profesinya sebagai seorang guru dibangun dan dikembangkan sehingga benarbenar menjadi guru yang profesional.

Persentase banyaknya Guru Matematika SMP di Kabupaten Wonosobo yang Mengalami Kesulitan dalam Melaksanakan Kegiatan Pengembangan Profesi. Persentase jumlah guru matematika SMP di Kabupaten Wonosobo yang mengalami kesulitan dalam pelaksanaan kegiatan pengembangan profesi secara umum dalam kategori sangat sedikit, Rinciannya; pada subbagian pengembangan diri dalam kategori sangat sedikit, pada subbagian publikasi ilmiah pada kategori sangat sedikit, dan pada subbagian karya inovatif pada kategori sangat sedikit. Apabila dibandingkan dengan Persentase jumlah guru matematika SMP di Kabupaten Wonosobo yang telah memahami dan yang telah melaksanakan serta yang mengalami kesulitan dalam pelaksanaan kegiatan pengembangan profesi maka dapat disajikan dengan tabel 9 .

Tabel 9. Perbandingan Persentase Jumlah Guru Matematika SMP di Kabupaten Wonosobo yang telah Memahami, Melaksanakan serta yang

Mengalami Kesulitan dalam Pelaksanaan Kegiatan Pengembangan Profesi

\begin{tabular}{lrc}
\hline & Persentase & Kategori \\
\hline Memahami & $61,24 \%$ & Sedang \\
Melaksanakan & $26,68 \%$ & Sedikit \\
Kesulitan & $20,67 \%$ & Sangat sedikit \\
\hline
\end{tabular}

Interpretasi data tersebut mengandung dua pengertian, yaitu: Pertama; Banyaknya guru matematika SMP yang telah memahami kegiatan pengembangan profesi lebih dari banyaknya guru yang melaksanakan kegiatan pengembangan profesi, dan banyaknya guru yang telah melaksanakan kegiatan pengembangan profesi lebih dari banyaknya guru matematika SMP yang mengalami kesulitan dalam melaksanakan kegiatan pengembangan profesi. Sebagian besar guru matematika SMP yang melaksanakan kegiatan pengembangan profesi tidak mengalami kesulitan dan sebagian kecil mengalami kesulitan. Jika yang terjadi demikian, maka berarti pelaksanaan kegiatan pengembangan profesi oleh guru matematika SMP di Kabupaten Wonosobo berlangsung secara wajar dan secara umum bisa dikatakan baik, karena demikianlah yang terjadi secara umum pelaksanaan/penerapan berbagai bidang ilmu pengetahuan yang dipelajari manusia. Pelaksanaan kegiatan pengembangan profesi oleh guru matematika SMP di Kabupaten Wonosobo berlangsung secara wajar dan secara umum dan dikatakan kurang baik jika dari 
banyaknya guru matematika yang melaksanakan kegiatan pengembangan profesi, yang banyaknya guru matematika SMP mengalami kesulitan lebih dari yang tidak mengalami kesulitan.

Kedua; hal tersebut merupakan temuan yang bermasalah dan harus ditemukan penyebab serta solusinya. Temuan tersebut adalah sebagian besar guru matematika SMP di Kabupaten Wonosobo memiliki pemahaman terhadap kegiatan pengembangan profesi (persentasenya dalam kategori sedang) dan tidak mengalami kesulitan (persentasenya dalam kategori sangat sedikit) jika akan melaksanakan kegiatan pengembangan profesi tetapi yang terjadi adalah yang melaksanakan kegiatan pengembangan profesi sangat sedikit (persentasenya dalam kategori sangat sedikit). Jika yang terjadi demikian maka ada beberapa kemungkinan penyebabnya, misalnya: belum ada niat untuk melaksanakan kegiatan pengembangan profesi, sedikitnya motivasi untuk melaksanakan kegiatan pengembangan profesi, belum mengetahui sanksi bagi guru yang tidak melaksanakan kegiatan pengembangan profesi. Alternatif solusinya antaralain guru matematika SMP di Kabupaten Wonosobo hendaknya; membangun keinginan yang kuat untuk memberi pelayanan yang terbaik bagi peserta didiknya dengan semangat Ibadah. Usaha memberi pelayanan terbaik kepada peserta didik yang ditulis menjadi karya ilmiah inilah inti kegiatan pengembangan profesi guru. Karya Ilmiah yang ditulis oleh guru dari suatu kegiatan pembelajaran yang memberikan pelayan terbaik kepada peserta didik memiliki multi fungsi bagi peserta didik, pribadi guru yang menulis, dan guru lain dan masyarakat umum yang membacanya. Dengan kata lain, kegiatan pengembangan profesi merupakan salah satu upaya guru untuk memberikan manfaat kepada diri sendiri dan kepada orang lain, sebagaimana tertulis dalam sebuah hadits yang maknanya sebagai berikut: Jabirradhiyallahu 'anhu bercerita bahwa Rasulullah shallallahu 'alaihi wasallam bersabda: "Sebaik-baik manusia adalah yang paling bermanfaat bagi manusia."(al-Albani, 2004, p.3289).

Upaya yang telah dilakukan oleh guru Matematika SMP di Kabupaten Wonosobo untuk Mengatasi Kesulitan dalam Melaksanakan Kegiatan Pengembangan Profesi tersebut diatas bervariasi antar guru tidak sama. Hal tersebut karena masing-masing guru berbeda dalam; tingkat pemahaman, tingkat kesulitan, tingkat kepedulian, tingkat motivasi, lingkungan tempat guru melaksanakan tugas, dan kesempatan guru matematika terhadap kegiatan pengembangan profesi. Walaupun demikian, upaya terbanyak yang telah dilakukan oleh guru matematika SMP untuk mengatasi kesulitan dalam melaksanakan kegiatan pengembangan profesi, diantaranya adalah: melaksanakan studi lanjut ke jenjang yang lebih banyak (S1/S2) untuk meningkatkan kompetensi diri sebagai guru matematika, mencoba melaksanakan penelitian tindakan kelas pembelajaran matematika walaupun belum membuat laporannya, mencoba membuat modul/diktat pembelajaran matematika, mempelajari Peraturan Menteri Negara Pemberdayaan Aparatur Negara dan Reformasi Birokrasi Nomor 16 Tahun 2009 tentang Jabatan Fungsional Guru dan Angka Kreditnya.

Diantara solusi yang penting untuk meningkatkan pelaksanaan kegiatan pengembangan profesi adalah membangun kompetensi kepribadian dan kompetensi sosial guru, agar dalam menjalankan tugasnya guru benar-benar berusaha bisa memberi manfaat kepada peserta didik serta memberi manfaat kepada rekan guru lain dari sisi keilmuan maupun dari sisi akhlaqul karimah. Membangun kompetensi kepribadian dan kompetensi sosial guru akan menumbuhkan kemauan yang banyak untuk mengembangkan profesionalitasnya, sehingga akan tercipta guru yang efektif yaitu guru yang mempunyai kemampuan (kompetensi profesional \& kompetensi pedagogik) yang banyak serta mempunyai kemauan (kompetensi kepribadian dan kompetensi sosial) yang banyak pula.

Solusi khusus (secara parsial) guru yang teridentifikasi mengalami kesulitan yang sama diajak berdiskusi untuk menentukan alternatif cara mengatasi kesulitan yang dialaminya dalam melaksanakan kegiatan pengembangan profesi. Dalam hal ini peneliti akan bekerjasama dengan forum MGMP Matematika SMP (baik di tingkat sekolah, pokja, maupun di tingkat kabupaten) atau Dinas Pendidikan Pemuda dan Olahraga di Kabupaten Wonosobo. Hal tersebut sesuai dengan pengertian MGMP yang ditetapkan oleh pemerintah dalam Standar Pengembangan MGMP sebagai berikut "MGMP (Musyawarah Guru Mata Pelajaran) adalah forum/wadah kegiatan profesional guru mata pelajaran pada SMP/MTs, SMPLB/MTsLB, SMA/MA, SMK/ MAK, SMALB/MALB yang berada pada satu wilayah/kabupaten/kota/kecamatan/sanggar/gug us sekolah". Melalui MGMP Matematika SMP diharapkan guru mempunyai pengalaman baru dan strategi pembelajaran baru yang lebih efektif dari hasil diskusinya dengan teman 
teman seprofesi sehingga meningkatkan prestasi belajar peserta didiknya.

Hal tersebut sesuai dengan yang nyatakan oleh Mundry, S (2005, p.1) bahwa " Experienced teachers who know both their content and effective instructional strategies tend to produce higher achievement outcomes among their students. Studies have found that children who are taught by several ineffective teachers in a row tend to perform less well than similar students who are taught by several more effective teachers in a row" Guru yang berpengalaman yaitu guru yang mengetahui baik isi maupun strategi pembelajaran yang efektif, cenderung menghasilkan hasil prestasi yang lebih banyak di antara peserta didiknya. Studi telah menemukan bahwa peserta didik yang diajarkan oleh beberapa guru yang tidak efektif secara berturutturut cenderung kurang baik jika dibandingkan dengan peserta didik yang sama yang diajarkan oleh beberapa guru yang lebih efektif secara berturut-turut.

\section{SIMPULAN DAN SARAN}

\section{Simpulan}

Persentase jumlah guru matematika SMP di Kabupaten Wonosobo yang telah memahami kegiatan pengembangan profesi secara umum dalam kategori sedang, rinciannya; pada subbagian pengembangan diri dalam kategori banyak, pada subbagian publikasi ilmiah dalam kategori sedang, dan pada subbagian karya inovatif dalam kategori sedang.

Persentase jumlah guru matematika SMP di Kabupaten Wonosobo yang telah melaksanakan kegiatan pengembangan profesi secara umum pada kategori sedikit, Rinciannya; pada subbagian pengembangan diri dalam kategori sedang, pada subbagian publikasi ilmiah dalam kategori sangat sedikit, dan pada subbagian karya inovatif pada kategori sangat sedikit.

Persentase jumlah guru matematika SMP di Kabupaten Wonosobo yang mengalami kesulitan dalam pelaksanaan kegiatan pengembangan profesi secara umum dalam kategori sangat sedikit, Rinciannya; pada subbagian pengembangan diri dalam kategori sangat sedikit, pada subbagian publikasi ilmiah pada kategori sangat sedikit, dan pada subbagian karya inovatif pada kategori sangat sedikit.

Upaya yang telah dilakukan oleh guru matematika SMP untuk mengatasi kesulitan dalam melaksanakan ketiga kegiatan pengembangan profesi pada kegiatan pengembangan diri; melaksanakan studi lanjut ke jenjang yang lebih banyak (S1/S2) untuk meningkatkan kompetensi diri sebagai guru matematika. Pada kegiatan publikasi ilmiah pendidikan matematika; mencoba melaksanakan penelitian tindakan kelas pembelajaran matematika dan membuat laporannya. Pada kegiatan pembuatan karya inovatif pendidikan matematika; mencoba membuat alat peraga pembelajaran matematika walaupun belum membuat laporannya.

\section{Saran}

Kepada Guru (termasuk peneliti); tumbuhkan semangat (hilangkan rasa malas) untuk melaksanakan kegiatan pengembangan profesi dalam rangka memberikan yang terbaik kepada peserta didik, tidak malu bertanya tentang berbagai hal tentang kegiatan pengembangan profesi guru matematika SMP kepada teman sejawat atau kepada pihak-pihak yang terkait, Jika harus meninggalkan sekolah untuk mengikuti kegiatan pengembangan profesi maka siapkan tugas untuk peserta didik, dan setelah selesai kegiatan pengembangan profesi segera mengkoreksi tugas yang sudah dikerjakan peserta didik. Kepada Sekolah; Memberikan dukungan dan bantuan kepada pendidik dan tenaga kependidikan untuk melaksanakan kegiatan pengembangan profesi, Menambah buku-buku referensi yang menunjang peningkatan keprofesian guru matematika serta mengakolasikan dana untuk peningkatan karier Pendidik dan Tenga Kependidikan, Memfasilitasi pengembangan media dan alat peraga pembelajaran matematika. Kepada Dinas Pendidikan; Mengusulkan kepada pemda program-program yang dapat meningkatkan profesionalitas guru untuk setiap mapel, Melaksanakan program-program yang dapat meningkatkan profesionalitas guru mapel matematika dan semua mapel, Bekerja sama dengan MGMP Matematika dan semua mapel, untuk menyelenggarakan kegiatan yang dapat meningkatkan profesionalitas guru matematika dan mapel lain. Kepada Pemerintah Daerah; Memasukkaan program kegiatan peningkatan profesionalitas guru dalam RABD, Memberi kesempatan kepada guru secara merata untuk mengikuti diklat dengan sharing anggara antara lembaga diklat dengan pemerintah kabupaten dalam program diklat kemitraan. Kepada Pemerintah Pusat; Mengevaluasi program peningkatan profesi guru yang telah dilaksanakan, dan membuat program baru yang lebih kreatif, inovatif, dan menarik bagi guru, Setelah menyelenggarakan diklat fungsional, 
hendaknya mengadakan monitoring dan evaluasi terhadap guru sebagai peserta diklat atas pelaksanaan hasil diklat fungsional. Kepada LPMP/ P4TKMatematika: Memfasilitasi penyelenggaraan kegiatan pengembangan profesi pengembangan diri guru matematika SMP, Mewadahi karya-karya ilmiah publikasi ilmiah kedalam jurnal pendidikan matematika dan pada tahap awal memberi kemudahan dalam hal prosedur pengiriman naskah/artikel pendidikan matematika yang akan dimuat pada jurnal pendidikan matematika. Kepada LPTK; Menyusun kurikulum dengan menjadikan kegiatan pengembangan profesi guru sebagai suatu mata kuliah pada jenjang S-2 atau ekstrakurikuler wajib pada jenjang $\mathrm{S}-1$

\section{DAFTAR PUSTAKA}

Al-Albani, M.N., (2004). Shahih Al- Jami' AshShaghir. Edisi III. (Terjemahan Imran Rosadi \& Andi Arlin). Damaskus: Al Maktab Al lslami (Buku asli terbit tahun 1988)

Brundrett, M., \& Silcock, P. (2002). Achieving competence,success and excellence in teaching. London and New York: Routledge Falmer.

Days, C. (2002). Developing teachers:the challenges of lifelong learning. London: Falmer Press.

Depdiknas. (2009). Peraturan Menteri Negara Pemberdayaan Aparatur Negara dan Reformasi Birokrasi nomor 16 tahun 2009 tentang Jabatan Fungsional Guru dan Angka Kreditnya

Depdiknas. (2013). Peraturan Menteri Pendidikan dan Kebudayaan Republik Indonesia nomor 65 tahun 2013 tentang Standar Proses Pendidikan Dasar dan Menengah

Desimone, L.M., et.al, (2002). Effects of Professional Development on Teachers' Instruction: Results from a Three-year Longitudinal Study. American Educational Research Association, Vol. 24, No. 2, pp. 81-112. (http://www. jstor.org/stable/3594138)

Direktorat jenderal PMPTK, Kemendiknas. (2010a). Pedoman pengelolaa pengembangan keprofesian berkelanjutan. Jakarta: Direktorat Profesi Pendidik.
Direktorat Jenderal PMPTK, Kemendiknas. (2010b). Pedoman pelaksanaan penilaian kinerja guru. Jakarta: Direktorat Profesi Pendidik.

Ebel, R.I, \& Frisbie, D.A. (1986). Essencial of educational measurement $\left(4^{\text {th }} e d\right)$. Engle Wood: Prentice-Hell, Inc.

Francis, N. (2012). Bilingual competence and bilingual profi ciency in child development. England: The MIT Press.

Garet, M.S., et.al. (2014). What makes professional development effective? results from a national sample of teachers. American Educational Research Journal Winter 2001, Vol. 38, No. 4, pp. 915945

Hatta, A. (2009). Tafsir qur'an perkata dilengkapi dengan asbabun nuzul \& terjemah. Jakarta: Maghfirah Pustaka.

Hidayatullah, F. (2009). Guru sejati membangun insan berkarakter, kuat dan cerdas. Surakarta: Yuma Pustaka

Leikin, R \& Zazkis, R. (2010). Learning through teaching mathematics development of teachers' knowledge and expertise in practice. London: Springer Science Business Media.

Mahsunah, D., etc all (2012). Kebijakan pengembangan profesi guru. Jakarta: Badan PSDMPK-PMP

Mundry, S. (2005). What Experience Has Taught Us About Professional Development. U.S. Department of Education, under grant numbers R319A000001, 2, $4,6,7,9,10,11,12$, and 13; and contract number RJ9707001

Republik Indonesia. (2005). Undang-undang Republik Indonesia nomor 14, tahun 2005, tentang guru dan dosen.

Taylor, I. (2007). A practical guide to assessment centres and selection methods. London and Philadelphia: Kogan Page Limited.

Winterton, J., \& Winterton, R. (2002). Developing managerial competence. London and New York: Routledge.

Yulaelawati, E. (2009). Kurikulum dan pembelajaran, filosofi teori dan aplikasi. Jakarta: Pakar Raya. 